\title{
Substituting Fish Meal with Pre-Treated Lima Bean Meal on Growth, Feed Utilization and Nutrient Retention in Clarias Gariepinus Fingerlings Reared in Hapa-in-Pond System
}

\author{
By Paulin Nyadjeu, Hapsatou Alim, Justin Djimbie Djopnang, \\ Achare Elvis Ayamba \& Minette Eyango Tabi-Tomedi
}

Abstract- The present study was conducted during 56 days to evaluate the effect of substituting fish meal (FM) with pre-treated Lima bean meal (LBM) on growth, feed utilization, and nutrient retention in Clarias gariepinus fingerlings weighing $3.00 \pm 0.02 \mathrm{~g}$. Four isonitrogenous ( $40 \%$ crude protein) diets containing $0 \%$ (D0), 25\% (D25), 50\% (D50) and 100\% (D100) of LBM, as FM substitute were used. D0 was considered a control diet. The results obtained indicate no significant difference in weight gain $(11.97 \pm 0.67 \mathrm{~g}$ and $12.95 \pm 2.12 \mathrm{~g})$, specific growth rate $(3.46 \pm 0.23 \% /$ day and $2.95 \pm 0.22 \% /$ day), protein efficiency ratio $(0.89 \pm 0.01$ and $1.05 \pm 0.02)$, protein retention $(10.83 \pm 0.23 \%$ and $12.48 \pm 0.19 \%)$ and lipid retention $(9.11 \pm 0.55 \%$ and $9.45 \pm 0.43 \%)$ of fish fed D0 and D100 respectively. Fish fed D25 and D50, showed significant growth increase, feed utilization performances, and both protein and lipid retention in comparison with D0 and D100. This study indicates that Lima bean meal can be used up to $50 \%$ in formulating feed for Clarias gariepinus fingerlings in rural areas.

Keywords: Clarias gariepinus fingerlings, fish meal, lima bean, growth, nutrient retention.

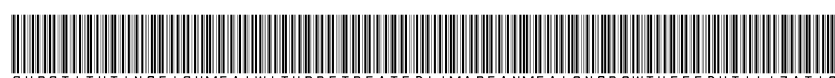

Strictly as per the compliance and regulations of:

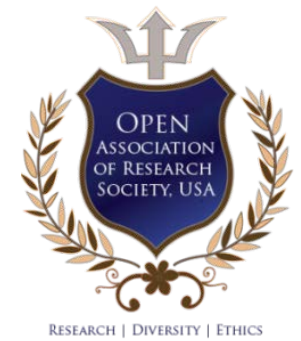

(C) 2019. Paulin Nyadjeu, Hapsatou Alim, Justin Djimbie Djopnang, Achare Elvis Ayamba \& Minette Eyango Tabi-Tomedi. This is a research/review paper, distributed under the terms of the Creative Commons Attribution-Noncommercial 3.0 Unported License http://creativecommons.org/licenses/by-nc/3.0/), permitting all non commercial use, distribution, and reproduction in any medium, provided the original work is properly cited. 


\title{
Substituting Fish Meal with Pre-Treated Lima Bean Meal on Growth, Feed Utilization and Nutrient Retention in Clarias Gariepinus Fingerlings Reared in Hapa-in-Pond System
}

\author{
Paulin Nyadjeu ${ }^{\alpha}$, Hapsatou Alim ${ }^{\sigma}$, Justin Djimbie Djopnang ${ }^{\circ}$, Achare Elvis Ayamba ${ }^{\omega}$ \\ \& Minette Eyango Tabi-Tomedi ${ }^{*}$
}

Abstract-The present study was conducted during 56 days to evaluate the effect of substituting fish meal (FM) with pretreated Lima bean meal (LBM) on growth, feed utilization, and nutrient retention in Clarias gariepinus fingerlings weighing $3.00 \pm 0.02 \mathrm{~g}$. Four isonitrogenous ( $40 \%$ crude protein) diets containing $0 \%$ (D0), 25\% (D25), 50\% (D50) and 100\% (D100) of LBM, as FM substitute were used. D0 was considered a control diet. The results obtained indicate no significant difference in weight gain $(11.97 \pm 0.67 \mathrm{~g}$ and $12.95 \pm 2.12 \mathrm{~g})$, specific growth rate $(3.46 \pm 0.23 \% /$ day and $2.95 \pm 0.22 \% /$ day $)$, protein efficiency ratio $(0.89 \pm 0.01$ and $1.05 \pm 0.02)$, protein retention $(10.83 \pm 0.23 \%$ and $12.48 \pm 0.19 \%)$ and lipid retention $(9.11 \pm 0.55 \%$ and $9.45 \pm 0.43 \%)$ of fish fed D0 and D100 respectively. Fish fed D25 and D50, showed significant growth increase, feed utilization performances, and both protein and lipid retention in comparison with D0 and D100. This study indicates that Lima bean meal can be used up to $50 \%$ in formulating feed for Clarias gariepinus fingerlings in rural areas.

Keywords: Clarias gariepinus fingerlings, fish meal, lima bean, growth, nutrient retention.

\section{InTRODUCTION}

$\longrightarrow$ ameroon is considered to be Africa in miniature because it presents a great geo-climatic diversity and a singular plurality of much diversified natural environments that seem to bring together most of the ecosystems of tropical Africa (Tchawa, 2012). These ecosystems are endowed with a rich terrestrial and ichthyologic biodiversity. Of this wealthy ichthyologic potential, only a small proportion such as Clarias gariepinus is currently known and valued. Clarias gariepinus is endemic to Africa, and it remains one of the most suitable species for local aquaculture (Cacot, 2006). It is a highly-valued species in aquaculture for its hardiness, its omnivorous diet, its fast growth, and the quality of its flesh (Ducarne and Micha, 2003; Tiogué et al., 2018). In Cameroon, aquaculture is widely practiced

Author $\alpha \sigma \omega ¥$ : Department of Aquaculture, Institute of Fisheries and Aquatic Sciences of Yabassi, the University of Douala, Cameroon. P.O. Box: 7236-Douala.e-mail: epauka@yahoo.fr

Author p: Department of Processing Quality Control of Aquatic Products, Institute of Fisheries and Aquatic Sciences of Yabassi, the University of Douala, Cameroon. P.O. Box: 7236-Douala. in rural areas where there are sufficient land coupled with enough water courses to supply fish ponds, where fish are mainly raised in semi-intensive cropping systems. Despite the country's natural potential, domestic production remains insufficient to meet the fish consumption needs of an ever-growing population. One of the major obstacles to fish production in general and catfish production, in particular, is the cost of production. Feed is one of the most costly resources in fish farming and, depending to the culture system, it represents $40-70 \%$ of the total cost of production (De Silva and Aderson, 1995). Fishmeal is an essential constituent in production of fish feed. It is the greatest protein source used in aquaculture feed because of its high protein content, good protein quality and balanced amino acid profile, high digestibility and palatability which is useful to enhance the uptake, digestion and absorption of nutrients in fish (Ariyawansa, 2000; Miles and Chapman, 2006). The use of fish meal for aqua feed industries is increasing by $10 \%$ every year, while the availability of fishmeal is declining due to over fishing of wild populations, consequently fish meal supplies witnessed significant fluctuations and also in prices during the last decade (Naylor et al. 2000; Rana et al., 2009; FAO 2014). There is, therefore, a pressing need to search for alternative protein sources that are cheap, available, of low human preference with little or no processing (Akinmutimi, 2001). Seeds of leguminous origin provide a promising alternative (Olaniyi et al., 2009a; Agbugui et al., 2011), one of such seeds is Lima bean (Phaseolus lunatus) which has potential for use in animal feed, fish inclusive, considering its relatively high protein content of about 28-30\% (Ajayi et al., 2010; Heuzé et al., 2015; Seidu et al., 2018).In most parts of Cameroon, Lima bean grows naturally in the fields. Because of its bitter taste, it is neglected in both human and animal foodstuffs, despite its nutritional value comparable to peas and cowpea. Like other grain legumes, it contains anti-nutritional factors that can be adequately eliminated or reduced to a tolerable limit using one or more processing techniques. According to Alonso et al. (2000), a variety of processing techniques 
such as soaking in water, heat treatment (soaking and boiling), roasting, fermentation and germination have been used to remove anti-nutritional compounds and hence improve bean nutritional values. Lima bean, if adequately processed, might be a valuable ingredient in fish food formula, and because of its relatively high protein content, it could be used to replace fish meal (Heuzé et al., 2015). The purpose of this study was to determine the effect of fish meal replacement with pretreated Lima bean meal on growth, feed utilization, and nutrient retention in Clarias gariepinus fingerlings.

\section{il. Material and Methods}

\section{a) Fish and rearing conditions}

The study was carried out in the technical

installations of the Common Initiative Group-Aquaculture Integrated of West (CIG-AIW) in the West Region of Cameroon. A total of 380 mixed-sex fingerlings of same brood stock of African catfish (Clarias gariepinus) weighing $3.00 \pm 0.02 \mathrm{~g}$ were obtained from the CIG-AIW hatchery. They were randomly distributed in 16 hapas $(1 \times 1 \times 1 \mathrm{~m}, \mathrm{~L}: \mathrm{W}: \mathrm{H})$ made up of mosquito net cloth and allowed for acclimation for four days before the experiment. During the acclimation, the fish were fed with a standard commercial feed. The hapas were suspended in an earthen pond $\left(200 \mathrm{~m}^{2}\right)$ with the help of four bamboo poles, one at each corner, such that threequarters of each hapa were submerged in water whereas one-quarter remained outside. The roof of the hapas was covered with mesh to stop fish from jumping out and to prevent natural predators (snakes, kingfishers, frogs) from getting in.

\section{b) Processing of Lima bean seeds}

Lima bean seeds used in this research work were harvested in April 2017 at Batié, in the West region of Cameroon. A set of Lima bean $(200 \mathrm{~g})$ were soaked in water, in a seed to water ratio of $3: 10(\mathrm{~kg} / \mathrm{L})$. Eleven hours after, the soaked beans were removed from water and immediately boiled in water at $100^{\circ} \mathrm{C}$ for three hours, with the water being changed after every hour (Adeparusi and Ajayi, 2004; Falaye et al., 2014). After boiling, the water was drained off and the boiled seeds were sun-dried, ground into a fine powder, then stored in an airtight container and kept at room temperature until use.

\section{c) Experimental diets and feeding regime}

Four isonitrogenous experimental diets were formulated with $40 \%$ protein. The first control diet (D0) containing $18.58 \%$ fish meal (FM) as the primary source of animal protein without the Lima bean meal (LBM), and three test diets D25, D50, and D100 where fish meal was replaced with Lima bean meal at 25\%, 50\% and $100 \%$. Two commercial feeds, a floating imported commercial feed called Coppens (C1) and a sinking locally manufactured commercial feed, named minepia- feed (C2). These feeds were used as second, and third control diets. For the test diets (D25, D50 and D100), the level of other ingredients were adjusted to maintain the same dietary protein when LBM was incorporated at $25 \%, 50 \%$ and $100 \%$. The vitamin, mineral mix, cassava flour, and palm oil as lipid sources were kept constant in all diets. In preparing experimental diets, the dried ingredients were ground into fine particles. After weighing, and mixing manually for 10 minutes, the preparations were moistened with warm water $\left(400 \mathrm{ml} \mathrm{kg}^{-1}\right)$, and mixed for another 20 minutes. During the mixing, palm oil was added slowly along with warm water to achieve proper consistency. The resulting mixture was then passed through a meat extruder to obtain a $2 \mathrm{~mm}$ pellet. The pelleted feeds were collected in flat trays and sun-dried for 36 hours, after which they were crunched into crumps by breaking them with the hand. The broken crumps were packed in polythene bags, sealed and appropriately labeled before stored in a freezer. Each sample of the dried experimental diet was subjected to proximate analysis according to the method of Association of Official Analytical Chemistry (AOAC, 1990) to determine the percentage composition of the various components of the diet. Moisture was analyzed by drying the sample in an air convection oven at $105{ }^{\circ} \mathrm{C}$ overnight. Crude protein was analyzed by the Kjeldahl method after acid digestion (\% crude protein = $\%$ nitrogen $\times 6.25$ ), while crude lipid was determined by extraction with petroleum ether using the Soxhlet method. The ash content in the diet was analyzed by combustion of samples in a muffle furnace at $550{ }^{\circ} \mathrm{C}$ for $12 \mathrm{~h}$ (table 1). 
Table 1: Ingredients, and proximate composition of experimental diets (g/100g dry mater)

\begin{tabular}{lcccc}
\hline \multicolumn{1}{c}{ Ingredients } & D0 & D25 & D50 & D100 \\
\hline $\begin{array}{l}\text { \% replacement of FM with } \\
\text { LBM }\end{array}$ & $0 \%$ & $25 \%-$ & $50 \%$ & $100 \%$ \\
\hline Fish Meal & 18.58 & 13.94 & 9.90 & $/ /$ \\
Lima Bean Meal & $/ /$ & 4.65 & 9.29 & 15.30 \\
Soybean cake & 18.58 & 20.14 & 21.69 & 24.90 \\
Cotton seed cake & 18.58 & 20.14 & 21.69 & 24.90 \\
Groundnut cake & 18.58 & 20.14 & 21.69 & 24.90 \\
Wheat bran & 7.82 & 5.45 & 3.17 & $/ /$ \\
Rice bran & 7.82 & 5.55 & 3.17 & $/ /$ \\
CMAV 5\% & 5 & 5 & 5 & 5 \\
Palm Oil & 4 & 4 & 4 & 4 \\
Cassava flour & 1 & 1 & 1 & 1 \\
\hline Proximate composition (\%.DM) & & & & $38.95 \pm 0.08$ \\
\hline Protein & $39.99 \pm 0.40$ & $39.65 \pm 0.30$ & $39.48 \pm 0.58$ & $7.70 \pm 0.14$ \\
Lipid & $7.05 \pm 0.07$ & $8.70 \pm 0.14$ & $8.85 \pm 0.9$ & $8.95 \pm 0.40$ \\
Ash & $7.25 \pm 0.30$ & $6.55 \pm 0.07$ & $6.25 \pm 0.30$ & $17.48 \pm 1.27$ \\
Moisture & $8.10 \pm \pm 0.14$ & $7.50 \pm 0.18$ & $8.90 \pm 0.14$ & \\
Energy (kJ/g DM) & $17.00 \pm 1.06$ & $17.45 \pm 0.99$ & $17.40 \pm 1.06$ & \\
\hline
\end{tabular}

d) Experimental procedure and water quality monitoring

Before the start of the experiment, 20 fingerlings were sacrificed and used to determine the initial carcass proximate composition. The rest of the fish, randomly distributed in 18 hapas of 20 fish each was divided in triplicate into six feeding treatments named C1 (Coppens), C2 (minepia-feed), D0 (normal diet or control diet), D25, D50, and D100 corresponding to diets where FM was replaced with LBM at 25\%, 50\%, and $100 \%$. Before the beginning of the feeding trials, fingerlings were starved for 24 hours to increase appetite and reception for new diets.All the fish in each hapa were counted and bulk weighed. They were handfed to apparent satiation with outmost care to minimize feed waste three times daily (09:00 a.m, 13:00 p.m and 17:00 p.m respectively) at a rate of $3-5 \%$ of their body weight. Growth was monitored through intermediate samplings carried out every 14 days, by counting and recording bulk weights of three separate subsamples from each hapa(representing approximately $30 \%$ of the population), using a scoop net of fish concentrated in the corner of the hapa. Fish were starved for 24 hours before sampling in order to limit stress and mortality related to handling. Feeding rates were then adjusted based on the weight gain of each group of fish per fourteen days. At the end of the experiment, a sample of three fish per hapa was randomly collected and sacrificed for the measurement of final whole-body proximate composition.

Water quality parameters in each hapa were measured daily before feeding. The temperature was measured using a Maximum-minimum thermometer; $\mathrm{pH}$ was monitored using electronic $\mathrm{pH}$ meter, dissolved oxygen $\left(\mathrm{O}_{2}\right)$ was determined using JBL Test Kits, nitrate $\left(\mathrm{NO}_{3}^{-}\right)$, nitrite $\left(\mathrm{NO}_{2}^{-}\right)$and ammonia $\left(\mathrm{NH}_{3}\right)$ were measured using Test strips (JBL Easy Test 6in1) (table 2).

Table 2: Water quality parameters (Mean \pm SD) during 56 days of the experimental period

\begin{tabular}{lcc}
\hline Parameter & Value obtained & $\begin{array}{c}\text { Optimum values (Zaykov and } \\
\text { Staykov, 2013) }\end{array}$ \\
\hline Temperature, ${ }^{\circ} \mathrm{C}$ & $22.1 \pm 0.47$ & $8-35$ \\
Dissolved oxygen, mg. ${ }^{-1}$ & $6.66 \pm 0.78$ & $>5$ \\
$\mathrm{pH}$ & $7.55 \pm 0.8$ & $6.5-8.5$ \\
Ammonia,mg. $\mathrm{I}^{-1}$ & $0.14 \pm 0.01$ & $0.5-2$ \\
Nitrite, $\mathrm{mg} . \mathrm{I}^{-1}$ & $0.24 \pm 0.02$ & $<0.3$ \\
Nitrate, $\mathrm{Ig}^{-1}$ & $0.32 \pm 0.02$ & $<25$ \\
\hline
\end{tabular}

\section{e) Measurement of zootechnical parameters}

Growth performances, feed utilization, and nutrient retention were assessed by determination of weight gain (WG), specific growth rate (SGR), feed intake $(F I)$, condition factor $(K)$, feed conversion ratio
(FCR), protein efficiency ratio (PER), survival rate (SR), and nutrient retention (NR). Calculations were carried out using the following formulae: Weight Gain $(\mathrm{g})=$ final weight -initial weight; Specific growth rate (\%/day) = $100(\ln W 2-\ln W 1) / T$, where $W 1$ and $W 2$ were the initial 
and final weights respectively, and $\mathrm{T}$, the number of days in the experimental period; Survival rate $(\%)=$ final number of fish $\times 100 /$ initial number of fish; Condition factor $=100\left(\right.$ Weight $/$ Length $\left.^{3}\right)$; Feed intake $=$ total dry feed/number of fish; Feed conversion ratio $(F C R)=$ feed intake / live weight gain; Protein efficiency ratio (PER) $=$ live weight gain/protein fed, where Protein fed $=\%$ protein in diet $\times$ total diet consumed/100; Protein efficiency ratio $(\mathrm{PER})=$ wet weight gain / protein fed, where Protein fed $=\%$ protein in diet $\times$ total dietconsumed/100; Nutrient retention (\%) was calculated as: 100 ((Final carcass composition - Initial carcass composition) /Amount of nutrient fed)

\section{ili. Statistical Analysis}

All results were expressed as mean $\pm \mathrm{SD}$. The data collected during every fish sampling were analyzed by one-way analysis of variance (ANOVA-1) repeated measure followed by Tukey's multiple comparisons test with $n=3$ replications containing 20 fish each. Differences were regarded as significant when $\mathrm{P}<0.05$; All statistical analyses were conducted using GraphPad Prism version 6.0.

\section{Results}

\section{a) Growth performances}

Growth performances of Clarias gariepinus fingerlings fed with the control and experimental diets in terms of weight gain, daily weight gain, and specific growth rate are presented in figures 1 and 2 . The weight gain curve (fig 1A), and the daily weight gain curve (fig 1B) obtained from the data recorded during fish sampling show almost the same evolution tendency. In general, the growth curve of C. gariepinus fingerlings was initially quite similar in all groups. But as from the $14^{\text {th }}$ day of the rearing period up to the end of the experiment, it is observed a significant $(p<0.05)$ size variation of fish that received Coppens (C1) diet compared to the rest of fish in other groups; followed by fish fed with diet D25, and D50 compared to C2, D0, and D100. At the end of the experimental period, fingerlings of $C$. gariepinus fed with C1, D25, and D50 present a weight gain of $33.19 \pm 2.14 \mathrm{~g}, 17.18 \pm 1.63 \mathrm{~g}$, and $18.17 \pm 2.75 \mathrm{~g}$ significantly $(\mathrm{p}<0.05)$ high by $77.22 \%$, $55.88 \%$, and $58.28 \%$ respectively to $\mathrm{C} 1, \mathrm{D} 25$, and D50, compared to C2 $(7.58 \pm 1.83 \mathrm{~g})$ and by $63.93 \%, 30.33 \%$, and $34.12 \%$ respectively, compared to control diet D0 $(11.97 \pm 0.67 \mathrm{~g})$.
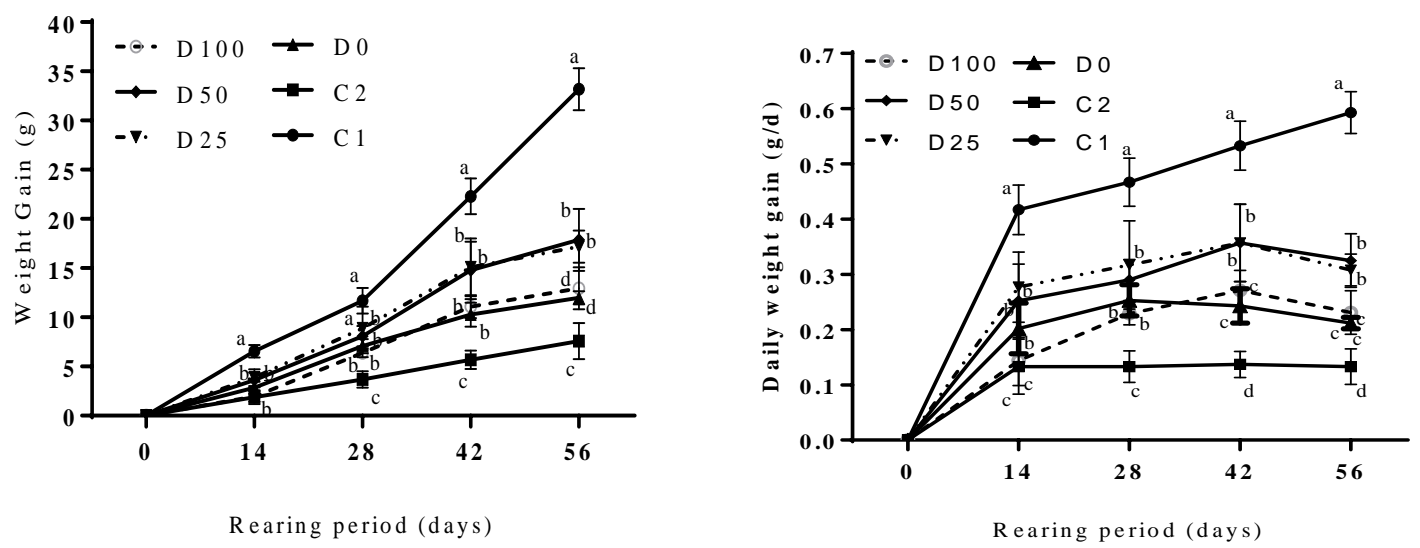

Figure 1: Mean weight gain (A), and daily weight gain (B) of Clarias gariepinus fingerlings fed on experimental diets for 56 days. Means on the same rearing period carrying the same superscript were not significantly different at $p<0.05$

The specific growth rate of Clarias gariepinus fingerlings to the experimental diets depending to the rearing period is presented in figure 2 . During the first sampling, fish in group C1 $(8.25 \pm 0.53 \%$ / d) showed the most significant increase in the specific growth rate, followed by that in groups D25 $(5.85 \pm 0.85 \% / d)$ and D50 (5.45 $\pm 1 \%$ / d) compared to C2 $(3.40 \pm 1.02 \% / d)$, and D0 (4.69 $\pm 0.78 \% / d)$. This specific growth rate then decreased in all groups to stabilize at the $56^{\text {th }}$ day of experimentation around values significantly high of $50 \%$ and $35.58 \%$ in the fish of group C1 $(4.44 \pm 0.11 \% /$ d) compared to the fish of the groups C2 (2.22 $\pm 0.29 \%$ / d) and D0 (2.86 $\pm 0.08 \%$ / d) respectively. In the D25 group $(3.39 \pm 0.15 \% / d)$ and D50 (3.46 $\pm 0.23 \% / d)$ the specific growth rates also remained significantly high by $34.51 \%$ and $15.63 \%$ and by $35.83 \%$ and $17.34 \%$,respectively to D25 and D50 as compared to C2 and D0. 


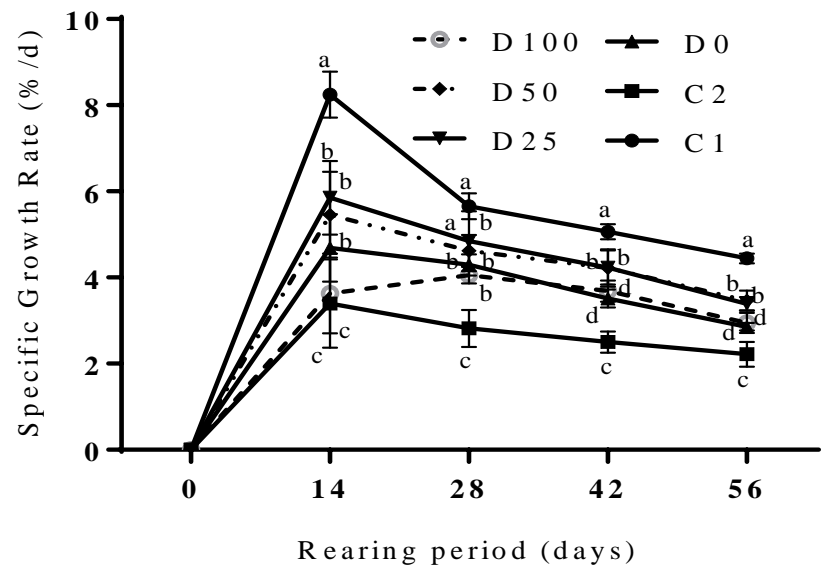

Figure 2: Specific growth rates of Clarias gariepinus fingerlings fed on experimental diets for 56 days. Means on the same rearing period carrying the same superscript were not significantly different at $p<0.05$

\section{b) Survival and feed utilization}

Table 3 below illustrates the survival and feed utilization in C. gariepinus fingerlings after 56 days of feeding. It can be noted that only two mortalities were recorded in fish fed with diets C2 and D100, respectively. Regarding feed efficiency, it can be noticed that no significant difference was observed between the experimental groups (D25, D50, and D100) compared to the control group D0. Nevertheless, the best values of food conversion ratio $(1.12 \pm 0.02)$ and protein efficiency ratio $(2.23 \pm 0.04)$ were obtained in fingerlings fed with diet C1 followed by that in diets $\mathrm{D} 25(\mathrm{FCR}=1.80 \pm 0.05$, $P E R=1.39 \pm 0.04) \quad$ and $D 50 \quad(F C R=1.88 \pm 0.08$, $P E R=1.33 \pm 0.06$ ) which are significantly different $(p<0.05)$ compared to that in diets $C 2(F C R=3.58 \pm 0.03$, $\mathrm{PER}=0.70 \pm 0.01) \quad$ and $\quad \mathrm{D} 0 \quad(\mathrm{FCR}=2.80 \pm 0.02$, $\mathrm{PER}=0.89 \pm 0.01)$.

Table 3: Survival and feed utilization of Clarias gariepinus fingerlings at the end of the feeding trial

\begin{tabular}{ccccccc}
\hline Parameter & \multicolumn{2}{c}{ Control diets } & \multicolumn{4}{c}{ Experimental diets } \\
\hline C1 & C2 & D0 & D25 & D50 & D100 \\
\hline IN & 60 & 60 & 60 & 60 & 60 & 60 \\
FN & 60 & 58 & 60 & 60 & 60 & 58 \\
IB (g) & 176.6 & 177.2 & 180 & 180 & 174.5 & 175.4 \\
FB (g) & 2148 & 603.2 & 855 & 1192 & 1288 & 965 \\
SR (\%) & $100 \pm 00^{\mathrm{a}}$ & $97 \pm 5.77^{\mathrm{a}}$ & $100 \pm 00^{\mathrm{a}}$ & $100 \pm 00^{\mathrm{a}}$ & $100 \pm 00^{\mathrm{a}}$ & $97 \pm 3.00^{\mathrm{a}}$ \\
FI (g/fish) & $36.84 \pm 0.5^{\mathrm{a}}$ & $26.39 \pm 1.63^{\mathrm{b}}$ & $31.48 \pm 0.02^{\mathrm{ab}}$ & $30.42 \pm 0.38^{\mathrm{ab}}$ & $34.92 \pm 1.66^{\mathrm{ab}}$ & $32.46 \pm 0.95^{\mathrm{ab}}$ \\
FCR & $1.12 \pm 0.02^{\mathrm{a}}$ & $3.58 \pm 0.03^{\mathrm{b}}$ & $2.80 \pm 0.02^{\mathrm{b}}$ & $1.80 \pm 0.05^{\mathrm{a}}$ & $1.88 \pm 0.08^{\mathrm{a}}$ & $2.38 \pm 0.06^{\mathrm{ab}}$ \\
FER & $89.22 \pm 1.88^{\mathrm{a}}$ & $27.90 \pm 0.31^{\mathrm{b}}$ & $35.74 \pm 0.30^{\mathrm{b}}$ & $55.47 \pm 1.63^{\mathrm{d}}$ & $53.23 \pm 2.52^{\mathrm{d}}$ & $41.97 \pm 1.17^{\mathrm{e}}$ \\
PI (g/fish) & $14.73 \pm 0.2^{\mathrm{a}}$ & $10.56 \pm 0.65^{\mathrm{b}}$ & $12.59 \pm 0.01^{\mathrm{ab}}$ & $12.17 \pm 0.15^{\mathrm{ab}}$ & $13.97 \pm 0.66^{\mathrm{ac}}$ & $12.98 \pm 0.38^{\mathrm{ab}}$ \\
PER & $2.23 \pm 0.04^{\mathrm{a}}$ & $0.70 \pm 0.01^{\mathrm{b}}$ & $0.89 \pm 0.01^{\mathrm{b}}$ & $1.39 \pm 0.04^{\mathrm{a}}$ & $1.33 \pm 0.06^{\mathrm{a}}$ & $1.05 \pm 0.02^{\mathrm{ab}}$ \\
\hline
\end{tabular}

Mean within the row with different superscripts are significantly different at $\mathrm{p}<0.05$.IN, initial number; $\mathrm{FN}$, final number; IB, initial biomass; FB, final biomass; $\mathrm{SR}$, survival rate; FI, feed intake; FCR, food conversion ratio; FER, food efficiency ratio; $\mathrm{PI}$, protein intake; PER, protein efficiency ratio.

c) Whole-body proximate composition and nutrient retention

As shown in Table 4, the whole-body composition of the different fish groups (\% wet weight basis) and nutrient retention are significantly affected $(p<0.05)$ by the different dietary treatments. In all fish groups in general, there were no significant impact of dietary treatment on whole-body moisture, ash, lipid and energy contents. However, the whole-body protein contents of fish fed normal diet ( $D 0=11.69 \pm 0.30$ ) was significantly $(p<0.05)$ lower than that of fish fed experimental diets D25 $(16.33 \pm 0.62)$ and D50 $(16.73 \pm 0.01)$ as well as Coppens $(18.41 \pm 0.17)$. Nutrient retention of C. gariepinus juveniles obtained after 56 days of rearing indicates that, substitution of fish meal with Lima bean meal as well as Coppens diet (C1) significantly affects their nutrient retention. In fish fed experimental diets D25 and D50, as well as in those fed 
with the Coppens diet, the results show that the nutrient retention of dry matter, protein, lipid, ash and energy

significantly increased compared to control diets D0 and C2.

Table 4: Proximate composition of the whole body and nutrient retention

\begin{tabular}{|c|c|c|c|c|c|c|}
\hline \multirow[t]{2}{*}{ Parameter } & \multicolumn{2}{|c|}{ Control diets } & \multirow[b]{2}{*}{ Do } & \multicolumn{3}{|c|}{ Experimental diets } \\
\hline & $\mathrm{C} 1$ & $\mathrm{C} 2$ & & D25 & D50 & D100 \\
\hline \multicolumn{7}{|c|}{ Whole body Composition ${ }^{\mathrm{BC}}$ (\% or kJ/g WW) } \\
\hline Moisture & $69.57 \pm 0.32^{a}$ & $62.63 \pm 0.27^{\mathrm{a}}$ & $70.74 \pm 0.89^{a}$ & $66.55 \pm 0.32^{a}$ & $67.99 \pm 0.01^{\mathrm{a}}$ & $71.48 \pm 0.37^{a}$ \\
\hline Ash & $3.58 \pm 0.18^{\mathrm{a}}$ & $4.02 \pm 0.08^{\mathrm{a}}$ & $3.88 \pm 0.00^{\mathrm{a}}$ & $3.76 \pm 0.20^{\mathrm{a}}$ & $3.52 \pm 0.03^{\mathrm{a}}$ & $2.99 \pm 0.29^{a}$ \\
\hline Protein & $18.41 \pm 0.17^{a}$ & $15.13 \pm 0.58^{\mathrm{ab}}$ & $11.69 \pm 0.30^{b}$ & $16.73 \pm 0.01^{a}$ & $16.33 \pm 0.62^{a}$ & $11.69 \pm 0.15^{b}$ \\
\hline Lipid & $1.03 \pm 0.03^{\mathrm{a}}$ & $1.10 \pm 0.02^{\mathrm{a}}$ & $0.72 \pm 0.08^{\mathrm{a}}$ & $0.82 \pm 0.01^{a}$ & $0.82 \pm 0.00^{\mathrm{a}}$ & $0.53 \pm 0.02^{b}$ \\
\hline Energy & $4.69 \pm 0.17^{\mathrm{a}}$ & $5.77 \pm 0.14^{\mathrm{a}}$ & $4.39 \pm 0.26^{\mathrm{a}}$ & $5.10 \pm 0.04^{a}$ & $4.94 \pm 0.07^{\mathrm{a}}$ & $4.39 \pm 0.12^{\mathrm{a}}$ \\
\hline \multicolumn{7}{|c|}{ Nutrient Retention (\% intake) } \\
\hline Dry matter & $26.89 \pm 0.45^{a}$ & $11.16 \pm 0.01^{b}$ & $11.74 \pm 0.66^{b}$ & $19.13 \pm 0.17^{c}$ & $19.15 \pm 0.20^{\circ}$ & $13.10 . \pm 0.19^{b}$ \\
\hline Ash & $37.12 \pm 1.21^{\mathrm{a}}$ & $17.78 \pm 1.42^{\mathrm{b}}$ & $24.57 \pm 0.15^{c}$ & $26.72 \pm 1.68^{c}$ & $24.92 \pm 1.72^{\mathrm{c}}$ & $11.41 \pm 1.59^{b}$ \\
\hline Protein & $38.83 \pm 0.29^{a}$ & $10.58 \pm 0.39^{b}$ & $10.83 \pm 0.23^{b}$ & $22.48 \pm 0.65^{c}$ & $23.76 \pm 0.24^{c}$ & $12.48 \pm 0.19^{b}$ \\
\hline Lipid & $36.50 \pm 1.00^{\mathrm{a}}$ & $10.36 \pm 0.13^{b}$ & $9.11 \pm 0.55^{b}$ & $15.52 \pm 0.23^{c}$ & $16.17 \pm 0.05^{c}$ & $9.45 \pm 0.43^{b}$ \\
\hline Energy & $22.39 \pm 0.71^{a}$ & $9.05 \pm 0.21^{b}$ & $9.20 \pm 0.52^{b}$ & $15.18 \pm 0.02^{c}$ & $15.25 \pm 0.46^{c}$ & $10.94 \pm 0.18^{b}$ \\
\hline
\end{tabular}

IBC initial body composition, on \% wet weight basis, were: moisture: $73.50 \pm 2.12^{a}$; ash: $2.29 \pm 0.16^{b}$; protein: $10.59 \pm 0.47^{b}$; lipid: $0.94 \pm 0.06^{a}$; energy: $4.22 \pm 0.11^{\mathrm{a}} \mathrm{kJ} / \mathrm{g} \mathrm{WW}$

Data are presented as mean \pm standard deviation of three replicates groups of fish, with 15 fish per group $(n=3)$. Mean in each row with different superscripts have significant differences at $p<0.05$.

\section{Discussion}

Fish is an important foodstuff in Cameroon because of it high nutritional value. It is the main source of accessible or affordable animal protein for poor households in urban or semi-urban areas. Recent trends indicate that like else where, most natural fisheries have reached or exceeded maximum sustainable yields. Moreover, although aquaculture started in Cameroon as far back as the late 1940s, out of the national demand of about 400000t, the country "currently" meets only about half domestic demand for fish from fishing and aquaculture (180000t), with fish farming contributing less than $0.1 \%$ (Ndah et al., 2011). One of the reasons for low aquaculture production in general and fish farming in particular has been attributed to limited access to quality feed. In aquaculture, fish feed costs the maximum expenditure and this is because of using animal protein sources such as fish meal, known as the best dietary protein source because it is quite palatable, and provides an excellent balance of essential amino acids, fatty acids, and some other substances (Omoregie, 2001; Hardy, 2010). Moreover, fish meal is the preferred animal protein supplement in the diets of aquatic animals. It carries huge quantities of energy and serves as the benchmark ingredient in aquaculture diets because of its high nutrient content and digestibility (Udo et al., 2012). Fish meal in animal diets increases feed consumption, feed efficiency, and growth through better feed palatability, and also improves nutrient uptake, digestion, and absorption among other ingredients (Yisa et al., 2013; Rahman et al., 2016).

Results from the current study indicates that substitution of fish meal (FM) with Lima bean meal (LBM) at 25\% (D25) and 50\% (D50), just like Coppens feed, significantly increased the growth in $C$. gariepinus fingerlings, compared to those fed with the normal diet and diet in which FM was completely replaced with LBM. These results are in conformity with those obtained by Nyadjeu et al. (2018) on the effect of fish meal substitution with Lima bean meal on growth and feed utilization in common carp fry (Cyprinus carpio). Therefore, the results demonstrate that partial substitution of FM with LBM enhances nutrient utilization in C. gariepinus fingerlings, which was reflected in improved weight gain, specific growth rate, feed intake, feed conversion ratio, protein intake, and protein efficiency ratio. Even though some of the problems with the use of non-conventional vegetable protein sources in aquaculture feeding are poor palatability, decreased digestibility, and decreased both nutrient uptake and fish metabolism, with consequences on both the growth and health, are attributed to the antinutritional factors; it is known that feed processing such as cooking, increase nutrients digestibility in all aquatic species by enhancing the action of the secretions of gastric juices and intestinal enzymes (Moro et al., 2017; Liu et al., 2017). Thus, the best growths observed in fish fed D25 and D50 could be partially attributed to different methods of treating Lima bean seeds before use. 
Previous studies have shown that different processing methods, such as soaking and cooking, effectively reduce the antinutrients content (trypsin inhibitor, oxalate, saponin and phytates) and improve the nutritional value of Lima bean (Jayalaxmi et al., 2016, Farinde et al., 2018). According to Mortuza et al. (2009) and Seidu et al. (2018) Lima bean, like all legumes, contains high concentrations of all essential amino acids except methionine/cysteine, which can be overcome by supplementing the diet with cereal proteins. It is known that essential amino acids such as lysine, methionine, tryptophan and arginine are the essential limiting amino acids that determine the growth and body development of higher vertebrates as well as fish. As fishmeal is an excellent source of the above-mentioned essential amino acids in fish feed (Pike and Barlow, 2003), the beneficial effects of experimental diets (D25 and D50) on fish growth performance could be attributed to the combined action of these nutrients supplied by Lima bean meal and supplemented by those of fishmeal and other ingredients such as soybean cake, rice bran, wheat bran. The results of the present work showed that alternative protein source is well utilized by the $C$. gariepinus fingerlings, because the experimental diets fed groups showed significant improvement in survival, weight gain, specific growth rate, and nutritional indices such as feed convention ratio and protein efficiency ratio. In the present study, the values of the feed convention ratio of Lima beans meal substituted groups were significantly lower than in the control group with the protein efficiency ratio comparatively higher in the experimental groups than in the control group. These results indicate that partial substitution of fish meal with Lima bean could improve the profitability of $C$. gariepinus fish farming by reducing the cost of production due to the shortening of the production cycle and the use of less quantity of feed for a large production.

Fish perform all its bodily functions such as feeding, growth, respiration, excretion and reproduction in water. These functions are directly affected by the water quality which refers to all the physical, chemical and biological factors that influence its use. Therefore, the success of an aquaculture operation depends on the water quality parameters that need to be monitored and controlled. Water quality parameters such as temperature, $\mathrm{pH}$, dissolved oxygen, nitrite, nitrate and ammonia recorded throughout the present study were consistent with the findings of Adebola et al. (2015), Okomoda et al. (2016) and Ajang et al. (2019). Thus, the only mortality observed in groups C2 and D100 would not be attributed to the quality of the water, but probably to the stress induced by the handling of the fish since this mortality was observed one to two days after the fish sampling. The water quality parameters recorded throughout this work proved to be adequate for the good survival of Clarias gariepinus fingerlings. These parameters have also been found to be suitable to induce good growth in Clarias gariepinus fingerlings through the maintenance of good physiological conditions which can be reflected through the carcass composition and the nutrient retention in the fish produced.

Carcass composition of Clarias gariepinus fingerlings fed all diets have more protein retained in the body at the end of the experiment compared to the start of the experiment. This is an indication that the protein to energy ratio in all diets formulated were enough to meet the energy need of the fish and so there was no sparing of protein to energy hence the reduction in lipid deposits in the carcass of fish fed experimental diets D25 and D50 since dietary lipids function as a ready source of energy for fish metabolic activity. Tiamiyu et al. (2014) made similar observations when they were evaluating the growth performance of Clarias gariepinus fingerlings fed with varying levels of Luffa cylindrical meal in outdoor hapas; Okomoda et al. (2017) also obtained similar results during the nutritional evaluation of toasted Mucuna utilis seed meal and its utilization in the diet of Clarias gariepinus (Burchell, 1822). Body composition is the resultant of nutrient retention that refers to feed nutrient proportion stored as a nutrient in fish body tissue during the rearing process. Thus, better carcass composition is an indication of a good nutrient retention of mainly proteins and lipids, which are of particular interest in nutritional studies due to their association with the quality of the product, and also because they serve as important indicators of true growth involving an increase in the structural tissues such as muscles (Fafioye et al., 2005; Zehra and Khan, 2012). The present study shows that both protein and lipid retentions of $C$. gariepinus juvenile obtained after feeding with D25 and D50, like Coppens, were significantly greater in comparison with those of fish fed D0 and D100. These results are in accordance with the findings of Syahailatua et al. (2017) who studied the effect of artificial feed composition for growth and protein and fat retention of humpback grouper, Cromileptes altivelis; they clearly indicate that $C$. gariepinus fingerlings fed D25 and D50 would have optimally used the feed so that the body weight increases obtained were due to optimum digestion, absorption, and being able to convert feed nutrient into flesh. Thus, the low nutrient retention observed in fish fed C2, D0 as well as D100 feed that could be explained by poor digestibility with insufficient absorption of nutrients in the digestive tract and poor conversion of these nutrients to the flesh, could be a partial justification for the low growth observed in fish from these groups.

\section{Vi. Conclusion}

The present study showed that partial substitution of fish meal by Lima bean meal up to $50 \%$ in 
the diet of Clarias gariepinus fingerlings had improved the overall performance in terms of growth response, feed utilization and nutrient retention. Thus, the use of Lima bean meal as a possible alternative feed ingredient in the diet of $C$. gariepinus fingerlings could reduce the cost of feed, and increase the fish farmer's income. Future studies, therefore, can be carried out to evaluate the effects of the inclusion level of this unconventional feedstuff ingredient in the diet of African catfish juveniles and other species as Tilapia.

\section{Competing Interests}

The authors declare that there are no competing interests regarding the publication of this paper.

\section{ACKNOWLEDGMENTS}

The authors wish to thank Mr. Michel DIOGNI, head of the fish farm "GIC AIO in Batié"for the reception and the provision of technical equipment necessary for the realization of this research work.

\section{References Références Referencias}

1. Adebola, O.A., Adetunji, Q.A. 2015. Effects of Water Level on Growth, Nutrient Utilization and Survival of African Catfish, Clarias gariepinus. International Journal of Agricultural Sciences and Natural Resources, Vol. 2(4): 109-112.

2. Adeparusi, E.O., Ajayi, A.D. 2004. Hematological characteristics of Nile Tilapia (Oreochromis niloticus) fed differently processed Lima bean (Phaseolus lunatusL.) diets. J. Res Sci. Manage, 2: 73-80.

3. Agbugui, M.O., Oniye, S.J., Auta, J., Abeke, F.O. 2011. Growth performance and feed Utilization of Fingerlings of Clarias gariepinus (Teugels) Fed Processed Paulatia monandra (Kurz) Seed meal. Journal of Aquatic Science, 26(1): 12-31.

4. Ajang, R.O., Ivon, E.A., Ndome, C.B., Ayim, E.M., Akaninyene, P.J. 2018. Economic Performance of Clarias gariepinus Juveniles Fed Separately with Factory and Farm-Made Diets. Asian Journal of Environment \& Ecology, 8(4); 1-11; Article no.AJEE.431512019.DOI:10.9734/AJEE/2018/v8i430081

5. Ajayi, F.T., Akande, S.R., Odejide, J.O., Idowu, B. 2010. Nutritive evaluation of tropical under-utilized grain legume seeds for ruminant's nutrition. J. Am. Sc, 6(7): 1-7.

6. Akinmutimi, A.H. 2001. Soaked and toasted Lima beans (Phaseolus lunatus) in broiler chickens diets: Effects on haematological parameters and blood chemistry. In: Meeting the challenges of an-imal production in new millennium (C.O. Ubosi, A. Kibon, I.D. Kwari, J.U. Igwebuike, I.D. Mohammed, N.K. Alade, F.I. Abbator and S.B. Adamu) (Eds) 6th Annual Conference of the Animal Science
Association of Nigeria, University of Maiduguri, Maiduguri convocation square, pp: 48-49.

7. Alonzo, R.A., Aguine., Marzo, F. 2000. Effects of extrusion and traditional processing methods on antinutrients and in vivo digestibility of protein and starch in faba and kidney beans-effect of extrusion cooking on digestibility. Food Chem, 68: 159-165.

8. AOAC. Official Methods of Analysis.1990. Association of Official Analytical Chemists, $15^{\text {th }}$ edition, Washington, D. C. 1298 pp.

9. Ariyawansa, S. 2000. The evaluation of functional properties of fish meal, The United Nations Univ. Fish. Training Prog, Final project. 25p.

10. Cacot, P.2006. Contribution to the improvement of fingerlings production in Cameroon: Breeding and nursery breeding trials with Clarias gariepinus and two other species. Mission carried out from 7 to 29 November 2006 as part of the ATP-CIROP project led by Olivier MIKOLASEK in collaboration with the IRAD station headed by David NGUENGA.60p.

11. De Silva, S.S., Aderson, T.A. 1995.Fish Nutrition in Aquaculture. Chapman and Hall, London, 319.

12. Ducarne, C.H., Micha, J.C. 2003.Intensive production technique of African catfish, Clarias gariepinus. Tropicultura, 21(4):189-198.

13. Fafioye, O.O., Fagade, S.O., Adebisi, A.A., Jenyo, O.. Omoyinmi, G.A.K. 2005. Effects of dietary soybeans (Glycine max (L.) Merr.) on growth and body composition of African catfish (Clarias gariepinus, Burchell) Fingerlings. Turkish Journal of Fisheries and Aquatic Sciences, 5(1): 11-15.

14. Falaye, A.E., Omoike, A., Orisasona. 2014. Apparent digestibility coefficient of differently processed Lima Bean (Phaseolus lunatus L.) for Clarias gariepinus juveniles. J. Fish. Aquat. Sci, 9 (2): 75-84

15. FAO. (2014). Fisheries \& aquaculture. In: J. Graziano da Silva (Ed.). The state of world fisheries and aquaculture, opportunities and challenges (Vol. 4, pp. 40-41). Rome, Italy: Office of Knowledge Exchange, Research and Extension FAO, Viale delle Terme di Caracalla

16. Farinde, O.E., Olanipekun, T.O., Olasupo, B.R. 2018. Nutritional composition and antinutrients content of raw and processed Lima bean (Phaseolus lunatus). Annals. Food Science and Technology, 19(2): 250-264.

17. Hardy, R. W. 2010. Utilization of plant proteins in fish diets: Effects of global demand and supplies of fishmeal. Aquaculture Research, 41:770-776.

18. Heuzé, V., Tran, G., Sauvant, D., Bastianelli, D., Lebas, F. 2015. Lima bean (Phaseolus lunatus). Feedipedia, a programme by INRA, CIRAD, AFZ and FAO. http://www.feedipedia.org/node/267 Last updated on May, 11: 14:31.

19. Jayalaxmi, B., Vijayalakshmi, D., Usha, R., Revanna, M.L., Chandru, R., Ramanjini, G.P.H. 2016. Effect of different processing methods on proximate, mineral 
and antinutrient content of Lima bean (Phaseolus lunatus) seeds. Legume Research, 39 (4): 543-549. DOI:10.18805/Ir.v0iOF.7108

20. Liu, H., Jin, J., Zhu, X., Han, D., Yang, Y., Xie, S. 2017. Effect of substitution of dietary fish meal by soybean meal on different sizes of gibel carp (Carassius auratus gibelio): digestive enzyme gene expressions and activities, and intestinal and hepatic histology. Aquaculture Nutrition, 23: 129147. DOI: 10.1111/anu.12375.

21. Miles, R.D., Chapman, F.A. 2006. The Benefits of Fish Meal in Aquaculture Diets.UF/IFAS Extension. FA122. http://edis.ifas.ufl.edu/fa122.

22. Moro, G.V., Silva, T.S.C., Cyrino, J.E.P. 2017. Feed processing affected the digestibility of carbohydrate sources for dourado Salminus brasiliensis. Aquaculture Nutrition, 23: 40-45. DOI: 10.1111/anu. 12356.

23. Mortuza, G., Hannan, A., Tzen, J.T.C. 2009. Chemical composition and functional properties of Vicia faba L. from Bangladesh. Bangladesh Journal of Botany, 38(1): 93-97.

24. Naylor, R.L., Goldburg, R.J., Primavera, J.H., Kautsky, N., Beveridge, M.C.M., Clay, J., Folksn C., Lubchenco, J., Mooney, H., Troell, M. 2000. Effect of aquaculture on world fish supplies. Nature, 405:1016-1024.

25. Ndah, H.T., Knierim, A., Ndambi, O.A. 2011. Fish pond aquaculture in Cameroon: a field survey of determinants for farmers' adoption behaviour. The Journal of Agricultural Education and Extension, 17(4): 309-323. DOI 10.1080/1389224X.2011.576578.

26. Nyadjeu, P., Djopnang, J.D., Mbatchou, P.N., TabiTomedi, M.E., Tchoumbougnang, F. 2018. Effect of fish meal substitution with Lima bean meal on growth and feed utilization in common carp fry, Cyprinus carpio. Int J Biol Chem Sci, 12(2):812-21. DOI. https://doi.org/10.4314/ijbcs.v12i2.16.

27. Okomoda, V.T., Tiamiyu, L. O., Akpan, I.S. 2017. Nutritional evaluation of toasted Mucuna utilis seed meal and its utilization in the diet of Clarias gariepinus (Burchell, 1822).Journal of Applied Aquaculture, DOI: 10.1080/10454438.2017.1278733

28. Okomoda, V.T., Tiamiyu, L.O., Iortim, M. 2016. The effect of water renewal on growth of Clarias gariepinus fingerlings. Journal of Fisheries, 74: 2529.DOI: $10.1515 / \mathrm{cjf}-2016-0005$.

29. Olaniyi, C.O., Bini Omote, T., Gbadamosi, M. 2009 a. Growth Performance and Nutrient Utilization of Clarias gariepnus fed processed Mucuna seed meal. In Proceeding 34 Annual Conference, Nigerian Societyfor Animal Production, pp. 222-225.

30. Omoregie, E. 2001. Utilization and nutrient digestibility of mango seeds and palm Kernel meal by juvenile Labeo senegalenis (Antheriniformes: Cyprinidae). Aquaculture Research, 32:681-687.
31. Pike, I.H., Barlow, S.M. 2003. Impact of fish farming on fish stocks. Fish Farmer, 26(1): 14-16.

32. Rahman, M.D.M., Han, H-S., Kim, K-W., Kim, K-D., Lee, B-J., Lee, S-M. 2016. Apparent digestibility coefficients of the extruded pellet diets containing various fish meals for olive flounder, Paralichthys olivaceus. Fisheries and Aquatic Sciences, 2-8. DOI 10.1186/s41240-016-0027-7.

33. Rana, J., Siriwardena, S., Hasan, M. R. 2009. Impact of rising feed ingredient prices on aquafeeds and aquaculture production. In: FAO (Ed.), Fisheries and aquaculture technical paper (p. 63). Rome, Italy: Food, Agriculture Organization of the United Nations.

34. Seidu, K.T., Osundahunsi, O.F., Osamudiamen, P.M. 2018.Nutrients assessment of some Lima bean varieties grown in southwest Nigeria. International Food Research Journal, 25(2): 848-853.

35. Syahailatua, D.Y., Dangeubun, J.L., Serang, A.M. 2017. Artificial feed composition for growth and protein and fat retention of humpback grouper, Cromileptes altivelis. AACL Bioflux, 10(6):1683-1691.

36. Tchawa, P. 2012. "Le Cameroun : une «Afrique en miniature »? ». Les Cahiers d'Outre-Mer, 259: 319338. DOI : $10.4000 / \mathrm{com} .6640$.

37. Tiamiyu, L.O., Solomon, S.G., Satimehin, S.P.D. 2014. Growth performance of Clarias gariepinus fingerlings fed varying levels of Luffa cylindrical meal in outdoor hapas. Octa Journal of Biosciences, 2(1): 8-12.

38. Tiogué, T.C., Ambela, E.A.D., Nana, P., TomediTabi, E.M. 2018. Reproductive Performances of African Catfish Clarias gariepinus according to the Type of Hormones and Substrates in Recycled Water in Southern Cameroon. Asian Journal of Fisheries and Aquatic Research, 2(1): 1-10. DOI: 10.9734/AJFAR/2018/43825.

39. Udo, I.U., Ekanem, S.B., Ndome, C.B. 2012. Determination of optimum inclusion level of some plant and animal protein-rich feed ingredients in least-cost ration for African catfish (Clarias gariepinus) fingerlings using linear programming technique. Int J Oceanogra Marine Ecol Sys, 1:2435.

40. Yisa, A.G., Edache, J.A., Udokainyang, A.D., Iloama, C.N. 2013. Growth performance and carcass yield of broiler finishers fed diets having partially or wholly withdrawn fish meal. Int J Poultry Sci, 12:117-20.

41. Zaykov, A., Staykov, Y. 2013. Technologies in the freshwater aquaculture. Academic Publisher Trakia University, ISBN 978-945-338-058-9. (Bg).

42. Zehra, S., Khan, M.A. 2012. Dietary protein requirement for fingerling Channa punctatus (Bloch), based on growth, feed conversion, protein retention and biochemical composition. Aquacult Int, 20:383-395. DOI 10.1007/s10499-011-9470-8. 
